\title{
Signs of the Concept of Chaos in Kant's Thinking and Its Relationship with Jorge Luis Borges' Thinking
}

\author{
Pablo César Martín Meier \\ Universidad Católica Argentina \\ Universidad Nacional de Cuyo
}

\begin{abstract}
The concept of chaos is present in man from the origins of mankind. Philosophy is alien to this concept and proceeds to speculate about its reality. Both Kant and Borges were not indifferent to this speculation and in their works, we can find "the effort to explain or to approach" the concept of chaos. Our first aim is to demonstrate in Kant's The Critique of Judgement, and more precisely in The Analytic of the Sublime, what Kant understands as "chaos." Our second aim is to establish a relationship between Kant and Borges in some of Borges' tales. Finally, we aim at establishing whether this "language of chaos" can refer to a sort of communication which exceeds logic language, i.e., a sort of "mute logos."
\end{abstract}

Keywords: chaos, sublime, Kant, Borges, logos

Men are unable to understand this logos which always is, both before having listened to it and after having listened to it for the first time...

(Heraclitus, fragment 1)

The word chaos comes from Greek $\chi \alpha$ ó supposes a previous order of cosmos (Diccionario de la Lengua Española, 434). ${ }^{1}$ Chaos can also be considered as the rough and disorganized set of matter accumulated without order. With these approximations to the concept of chaos, we consider that chaos is the reality which lies out of the possibility of being classed by the human being or under the power of its definition. Chaos is the indefinable, the unexplainable.

This work has three aims: first, to investigate whether the concept of chaos is dealt with by Immanuel Kant in his The Critique of Judgement and which consequences result from the author's thinking. Second, we will analyze some writings by the Argentine author Jorge Luis Borges such as The Library of Babel, The Garden of Forking Paths, and The Aleph to determine whether the author has considered the concept of chaos in the cited writings and how this concept is dealt with by him. Last, we will aim to establish similarities between the thinker from Königsberg and the Latin American author.

To develop these aims, we have decided to divide this work into three parts. The first part is called "Kant and Chaos in the Analytic of the Sublime." In this part, we will develop the idea of how Kant understands chaos as part of the sublime and which consequences it brings to the faculty of imagination and to thought. The second part is called "Borges and Chaos." This part will be devoted to analyze the concept of chaos in the

Pablo César Martín Meier, Professor, Department of Philosophy, Universidad Católica Argentina (UCA), Argentina; main research field: Kant's Philosophy. 
above cited writings by Borges and how the concept of chaos has been dealt with by Borges. The last part is called "Objective Logos and Mute Logos." Here we will deal with similarities between Kant and Borges and we also with the concept of chaos as another form of Logos, that of Mute Logos.

\section{Kant and Chaos in the Analytic of the Sublime}

Kant starts The Analytic of the Sublime by establishing a distinction between the beautiful and the sublime. The beautiful refers to the shape of the object. Kant also understands the beautiful as an exposition of an undetermined concept of understanding. Finally, the beautiful arouses in the subject a feeling of drive for life. On the other hand, the sublime feeling becomes evident in the object "without shape." It is subject to reason and arouses in man a feeling of momentary suspension of the vital faculties, followed by an overflowing of these forces (Kant, KU, B 76). ${ }^{2}$

For the author, the sublime feeling arouses when the subject is contemplating that which goes beyond his forces and absolutely escapes his power of control, such as the uncontrolled forces of nature; or that which escapes the possibility of being measured by him. But this "sublime feeling" is not aroused by some specific object — an active volcano or the impressive storm—but it is man's own "spirit" which creates the sublime ideas.

We can only say that the object is suitable for exposing a sublimity which can be found in spirit, then the properly sublime cannot be locked up in any sensible way, but it only refers to ideas of reason, which, although no adequate exposition of them is possible, start moving and are brought to the spirit precisely by that inappropriateness which becomes apparent sensibly. (Kant, KU, B 76)

At the end of paragraph 23, Kant writes that the sublime is closely related to what breaks with established and organized rules, that is to say, chaos. The sublime, most of times, arouses in its chaos or in its wildest and most irregular disorder and destruction (Kant, KU, B 77). ${ }^{4}$ This chaos and wild disorder leave man unable of categorizing that reality, man remains "out in the open," without any possibility of action of the order of understanding. We could say, by paraphrasing Gramont, that it is an original experience where nothingness becomes part of this feeling.

The sublime becomes the proper name of this very archaic knowledge of a phenomenon which defies however our power of understanding — such as a moment out of language, out of logic which is not satisfied with delaying a discourse to our disposition or the beginning for its realization... The sublime is the proper name of this pure exterior from the phenomenon to the logotype in the absolute defeat of our faculties. The amorphous character of the sublime testifies that the work of our spirit does not carry any of the clues of the sublime. (Gramont 1996, 97) ${ }^{5}$

In paragraph 24 of The Critique of Judgement, Kant divides The Analytic of Sublime into two parts: The Mathematical Sublime and The Dynamic Sublime. The mathematical sublime is defined by the author as that what we call absolutely big (Kant, KU, B 81$)^{6}$ and does not correspond to a measurement of the logic or quantitative type, but it properly corresponds to the subjective aesthetic perspective, what cannot be compared to anything and which goes beyond any parameter of metrical measurement or any type of standard which could be used. ${ }^{7}$ However, Kant also explains that the need of thinking what is "immeasurable" arises from a need of the ideas of the reason and does not depend on any established sensible object.

The difference between the mathematical appreciation of magnitudes and the mathematical aesthetic appreciation consists in the following: On the one hand, the scale of the mathematical appreciation of magnitudes can reach the infinite. On the other hand, the mathematical aesthetic appreciation considers what is 
big, in a maximum which cannot be surpassed by any other subjective appreciation. But we should take into account that when the infinite is thought as the absolutely big, in which there is no possibility of measurement and superseding, then we are in presence of the mathematical sublime.

But this feeling of the sublime makes the imagination experience a feeling of pain which arouses from the inadequacy of the imagination (Kant, KU, B 97). ${ }^{8}$ This pain is felt because the mathematical sublime in its chaotic and boundless nature, with its measurement of the absolutely big without any possibility of having a measurement for comparison, makes the imagination serve no longer the understanding with its functions of reproduction and production of ways of thinking like in the first critique, but serve reason and be thrown to conceive the infinite. Since imagination cannot conceive the infinite and, according to Makkreel, the imagination is induced to fight to reach integrity in its relationship with time; then it suffers an unexpected reversion in its working order; it experiences a regression and suspends the progressive sequence of time (Makkreel 1984, 8). ${ }^{9}$

To measure a space (as apprehension) means at the same time to discover it; and therefore, it is an objective movement in the imagination and a progression (progressus). The understanding of plurality in unity, not of thought, but of intuition, therefore, of the successively apprehended at a certain moment, is, on the contrary, a regression (regressus) which cancels, for its part, the condition of time in the progression of imagination and makes simultaneity capable of being sensed. (Kant, $\mathrm{KU}, \mathrm{B} 97)^{10}$

Therefore, the imagination at service of reason leaves time aside in its lineal form to be able to work with simultaneity and the "instant," to be able to "feel" this infinite which exerts violence on simultaneity, and simultaneity feels the impossibility of knowing the instant with the parameters of understanding. Later, in paragraph 28, Kant is going to deal with the Dynamic Sublime: What characterizes the dynamic sublime is the strength which is superior to big obstacles (Kant, KU, B 101). ${ }^{11}$ This feeling emerges when man contemplates from the security of his existence the uncontrollable strength of a storm or the destructive power of a volcano. These phenomena bring man to ponder on the insignificance of his power. All this uncontrollable and chaotic power of nature arouses in man the feeling of fear. But Kant makes a difference between fear and fright. Fear is a feeling which emerges when contemplating the chaotic forces of nature or the power of God and the subject inwardly reflects on the insignificance of his own strength. On the other hand, fright is the feeling experienced by man because of the extinction of his own life and which, in the case of the contemplation of God, brings to superstition.

Rocks audaciously hung and; so to speak, threatening; clouds of storm which pile up in the sky and move forward with lightning and thunder, volcanoes in their almighty destructive power... etc, reduce our faculty to resist to an insignificant smallness, compared to their strength. But their appearance is the more attractive the more fearful, as long as we ourselves are in a safe place, and we call these objects sublime because they elevate the faculties of the soul above their ordinary happy medium and they bring us to discover in ourselves a faculty of resistance of a different kind. (Kant, KU, B 102) ${ }^{12}$

This dynamic judgement which shows an uncontrollable and defying strength also brings imagination to its tension, which somehow causes in it the suspension of the functions which it exerts at the service of understanding. By being forced by reason, reason makes imagination serve the practical sphere. ${ }^{13}$ Kant also asserts that the feeling of sublime must be favoured by education, which means that culture breeds this feeling. For the author the feeling of sublime is innate in man, but when man receives a good education, he has more tendencies to be able to experience it. ${ }^{14}$ 
However, when nature manifests itself in that way, in a wild way, our humanity seems completely neutralized; no synthesis of our spirit has started to evaluate, to measure, to understand yet, and this undecided attitude of our faculties constitutes precisely the difficulty and the extraordinary of the feeling of the sublime. There we touch the limit-point of our critical philosophy... how can we imagine nature before our thinking organizes it? Here we deal with the idea of pure nature, pure of all form, synthesis, pure representation of all that which makes nature possible for our determined spirit. (Gramont 1996, $106)^{15}$

In accordance to Gramont, the feeling of the dynamic sublime would produce an epoché or momentary suspension in the faculties of understanding, remaining man alone in a state of contemplation of those destructive and chaotic forces of nature; and, on the other hand, facing the possibility of an experience previous to all categorization.

\section{Borges and Chaos}

From the three texts chosen from Borges, two of them have as principal subject the labyrinth. In accordance to Alicia Jurado, the labyrinth is an image of the internal life of man, where the immense is represented, the insecurity - in one word - the chaotic. And, on the other hand, it also symbolizes man's need for control—never reached — of that uncertain and ungovernable future, which is presented to him as something impossible to be subjugated (Jurado 1964, 100). ${ }^{16}$

In 1941, Borges finished writing The Library of Babel. In accordance to Jaime Alazraki, this writing together with The Lottery of Babylon can be conceived as metaphors of chaos and chance. The library's chaos represents the universe (Alazrak 1977, 106). ${ }^{17}$ Borges asserts that the library is made of an infinite number of hexagonal libraries. He also tells us that the library is a sphere which centre is any hexagon (Borges 1941, 762). ${ }^{18}$

Both the universe and the library are complete, without any possibility of deciphering their origin or end. On the other hand, the library presents itself as a set of books unable to be interpreted. As a symbol of the universe, the library presents itself as the undeterminable, as the non-categorical, defined and limited in spite of its efforts to cover the universe.

The first one: The Library exists ab aeterno. The truth which immediate corollary is the future eternity of the world, no reasonable mind can doubt... The second one: The number of orthographic symbols is twenty-five. This verification made it possible, three hundred years ago, to formulate a general theory about the Library and satisfactorily solve the problem which no other speculation had deciphered: the formless and chaotic nature of almost all books. (Borges 1941, 762) ${ }^{19}$

Another important sign in this tale is the librarians, who try to decipher and categorize the code of the library. They represent man's effort to explain that which lacks any explanation under the parameters they know. They are the sign of culture which surrounds the universe of the library. On the other hand, and; in accordance to Antonio Pineda Cachero, this labyrinth is presented as an image of the immense; it is a world in which chaos destroys the representation of the organized world conceived by Kepler or Newton; in which uncertainty and probability play their part and break the image of the structured and rigid world (Pineda, 4 ). ${ }^{20}$

The content was also deciphered: notions about combinatory analysis, illustrated by examples of variations with unlimited repetition. These examples made it possible that a librarian of genius discovered the fundamental law of the Library. This thinker realized that all books, no matter how different they are, consist of the same elements: space, full stop, comma, the twenty-two letters of the alphabet. He also cited a fact which all travellers have confirmed: there are not, in the immense Library, two identical books. (Borges 1941, 763-4) ${ }^{21}$ 
In The Garden of Forking Paths, the author sets the action of the tale during the First World War in the year 1916. The main character is a citizen of Chinese origin called Yu Tsun and his mission is to find the new depot of the British artillery. He is a spy who works for the German government, and during his mission, he meets an Englishman called Stephen Albert, who is a sinologist. Besides, he is the only one who has found and has been able to decipher the labyrinth which his grandfather, Ts'ui Pên, had written and which nobody could understand. But the peculiarity about this labyrinth consists of not being a spatial labyrinth but a temporal one.

Regarding the structure of the tale, we can assert that it is a police story and the centre of the tale is Albert. The paradox and irony lie in the fact that the man who found and interpreted the labyrinth of his ancestor has to be killed to be able to communicate, by means of a hidden language, the place to be bombarded by the Germans, which was precisely called Albert (Alazrak 1977, 103). ${ }^{22}$ In the tale, we encounter the labyrinth when the main character walks into the garden and he finds a labyrinth in his grandfather's book.

The main subject in the tales is time, a time which does not correspond to the succession described by classical physics, but a time which breaks with these parameters and on which several other different times converge. At a given moment, Yu Tsun is a friend. At another moment, he is the enemy. At one moment, both Yu Tsun and Albert can survive. At another moment, one dies and the other one survives.

The garden of forking paths constitutes an incomplete image — but not a false one — of the universe such as Ts'ui Pên conceived it. In contrast to Newton and Schopenhauer, his ancestor did not believe in a uniform, absolute time. He believed in infinite series of times, in a growing and vertiginous web of divergent, convergent, and parallel times. This set of different times which approach, diverge, cut or ignore each other, covers all possibilities. We do not exist in most of these times. In some of them you exist but I do not. In some others, I exist but you do not. In some others, both you and I exist. (Borges 1941, 775-6) 23 $^{23}$

In this tale, the author tells us that this labyrinth is a labyrinth of time, and this time breaks the lineal and uniform "category of succession." Thus, the author opens the possibility for the "instant" on which all times can concur.

Finally, we will analyze The Aleph. The main character in this book is Borges. The book begins with Borges' memory of Beatriz Viterbo, who is dead. Then he mentions that he is going to visit his father and his cousin Carlos Argentino. Carlos Argentino calls Borges because his house is going to be demolished and he tells Borges about the existence of an extraordinary object called "Aleph." In accordance to Alazraki, this object is a supersensitive entity which manifests itself together with the whole of the universe in a microcosm. ${ }^{24}$ In the same text, the author mentions that aleph is the first letter of a sacred language. For the cabala, this letter represents the En Soph, the unlimited and pure divinity (Borges 1949, 931). ${ }^{25}$

What we are going to analyze is: Which is the characteristic of this strange object? The first characteristic that we analyze is the possibility to see all the places of the world, seen from all angles. ${ }^{26}$ This faculty of the object lets us break the successive temporal sequence which allows us to conceive the external spatiality to the subject.

The diameter of the Aleph could be of two or three centimetres, but the cosmic space was there, without any decrease of size. Everything (the glass of the mirror, for example) was infinite things, because I could clearly see it from all the points of the universe. I could see the populous see; I could see the dawn and the afternoon; I could see the masses of people of America; I could see a silver spider's web in the centre of a black pyramid; I could see a broken labyrinth (it was London); I could see never-ending eyes close to me, scrutinizing me as if they were scrutinizing on a mirror; I could see all the mirrors of the planet and none of them reflected me. (Borges 1949, 929) ${ }^{27}$ 
In this description, we can clearly see that the space and time parameters are broken, which are the immediate possibilities to experience empirical intuitions, which make possible the perception of the external and internal objects. In this tale, Borges breaks with the pure intuitions and gives possibility to the "instant." $\mathrm{He}$ makes it possible to break with the linearity of time and therefore conceive the simultaneous. Finally, Borges realizes that this experience of simultaneity in the instant can be experienced but is unlikely to be conceptualized in language.

In this immense instant, I have seen millions of pleasant or appalling acts; none of them has amazed me as much as the fact that all of them occupy the same point, without superseding and without transparency. What my eyes have seen was simultaneous; what I will transcribe, consecutive, because language is consecutive. (Borges 1949, 929) ${ }^{28}$

To end this part of the exposition, we can assert that in the first tale analyzed - The Library of Babel - the concept of the labyrinth is presented as the inaccessible and chaotic in man. In the second tale-The Garden of Forking Paths - the author develops the idea of time breaking with sequence to give way to the instant and simultaneity. And finally - in The Aleph — the concept dealt with is the suppression of the space-time sequence. Through the Aleph, one not only observes different points, objects, situations, etcetera; but also that, at the same time, the space-time order gets cancelled.

\section{Objective Logos and Mute Logos}

In the last part of our work, we will attempt to establish the relationship between Kant and Borges regarding the concept of chaos. For the German author, the process of knowledge is determined by intuition and thinking. In the introduction of The Critique of Pure Reason, Kant writes that all our knowledge starts with experience, but experience is not the cause of the origin of knowledge. The knowledge of the multiplicity of sensibility is organized by means of categories and knowledge is namely presented as a synthesis. Because of this synthesis, science can become science.

All knowledge needs a concept, no matter how imperfect and obscure this concept could be. But this concept, according to its form, is always something universal which is used as a rule. Thus, the concept of body, because of the unity of the multiplicity which is thought through it, is used as a rule for our knowledge of external phenomena. But it can be a rule of the intuition just because it represents the necessary reproduction of the multiplicity of the given phenomena, and therefore, [it represents] the synthetic unity in the conscience of them. (Kant, KrV A 60) ${ }^{29}$

In the case of Borges, although the author did not formulate or pretended to formulate a theory about knowledge, we can see in the three tales analyzed the contrast between man's effort to organize and present a structured image of the universe and the antithetical image of chaos, with its ungovernable reality and impossibility to be known. In The Library of Babel, Borges sets us in front of the tidy library made by man and which represents the culture which investigates the "other library:" the library that represents chaos, the library that definitely exists next to the library built by man's intelligence.

The human Library and the divine Library, culture and the universe, are confronted in the tale as a defy which defeat is previously announced from the first line of the tale; this Library that we call the universe is not the universe, but our invention of another universe. The inscrutable order of the gods, we call chaos; the other one, knitted as a human labyrinth, as a game of the intelligence, we call "the order of the universe". Clear example of meaning organized as a double metaphor which is supported by a single vehicle: the Library. (Alazraki 1977, 109) ${ }^{30}$ 
In the second tale, The Garden of the Forking Paths, as we have commented above- the subject analyzed is time. In this tale, we can observe lineal time, when the main character has to discover the depot of the artillery to inform his government; and, the "other time" which is not lineal but crossed by all the times in an instant. "I thought of a labyrinth of labyrinths, a sinuous growing labyrinth which embraced the past and the future and which somehow implied the stars. Absorbed in those illusory images, I forgot my destiny of a persecuted man. I felt, during an undetermined period of time, as an abstract perceiver of the world" (Borges $1941,771){ }^{31}$

In this tale, lineal time and the "other time" are confronted. Lineal time is measurable and quantifiable. It can be perceived by man. The "other time" breaks with linearity and measure and "chaos" starts to play a role; where the past, the present and the future gradually fade and converge into the instant.

Finally, in The Aleph, Borges, in the character of Carlos Argentino Daneri, represents the figure of the effort to construct the world, to give order and shape to it. His work-Borges says - is inefficient, since he will never be able to conceptualize what is never-ending. It is the opposite to the dynamic, to the never-ending of the space-time breaking which we have already analyzed in this tale in the second part.

Carlos Argentino is pink, robust and white-haired. He has fine features. He practices I don't know which secondary post at an illegible library on the outskirts of the South; he is authoritarian, but he is also inefficient... His mental activity is constant, passionate, versatile and absolutely insignificant. He abounds in too many useless analogies and in idle scruples. (Borges 1949, 922) ${ }^{32}$

Now, we can ask ourselves: Does it exist a relationship between what Kant and Borges think? We consider that the answer is affirmative. Without making an exhaustive exposition of the problem of knowledge in Kant's work, he considers two faculties with different functions and objectives: understanding and reason. In the first case, the understanding is in charge of developing the process of knowledge in man by means of a synthesis between the multiplicity received by the senses, and the own spontaneous action of understanding. In the second case, the objects of reason are limited to the practical sphere. However, in the experience of the sublime man is confronted to the immeasurable, the unclassifiable. He faces the impossibility of the synthesis of knowledge exerted by the understanding, the impossibility of the opening of reason.

The comparison that we propose consists of analyzing the characters in the tales by Borges-both the library and the librarians - and, in Kant's work, the image of the understanding which makes the effort to organize and synthesize knowledge. The labyrinth and the Aleph represent the chaotic and the immeasurable. This idea corresponds to the faculty of reason dealt with by Kant in his The Critique of Judgement. In Kant, the sublime also represents the immeasurable such as Gramont asserts:

Here, the undetermined of what it seems is not solved in any way with what the spirit can satisfy, the sublime does not lead us to the doors of the concept or the finality, but quite on the contrary. [The sublime leads us] To the doors of the atrocious and horrifying, which is close to chaos, where nature could have lost all meaning, but without never getting ruined there. The first moment when nothing is designated, no form, but where all language is caught out. (Gramont 1996, 96) ) $^{33}$

Finally, we will concentrate on the "logos." For Kant the concept of the "objective logos" represents the knowledge which remains disabled when trying to expose this sublime and chaotic experience. Indeed Borges shares this idea and asserts: what my eyes have seen was simultaneous; what I will transcribe, successive, because language is successive (Borges 1949, 929). ${ }^{34}$ The chaotic or sublime experience is contemplated, is experienced; but the objective logos or the word cannot be represented. It can only be approached by means of 
symbols in poetic language. For this reason, we dear postulate that this chaotic and sublime experience can be described as the "mute logos," because it is a vital experience, original and dynamic, which can only be contemplated and experienced but cannot be conceptualized. It tells us a lot, but it cannot be described. Looking for an analogy we could say that thus the wind is only visible when it bends the trees. Without resistance, even an impossible resistance, soon irascible, the savage-being of Nature could never show himself (Gramont 1996, 109). ${ }^{35}$

\section{Notes}

1. Diccionario de la Lengua Española. Madrid, Editorial Espasa Calpa, 2001, 434.

2. Kant, Immanuel. "Crítica del Juicio." Translation from German "Kritik der Urteilskraft" by Manuel García Morente. Buenos Aires: El Ateneo, 1951, 264.

3. Kant, Immanuel. "Crítica del Juicio." Translation from German "Kritik der Urteilskraft" by Manuel García Morente. Buenos Aires: El Ateneo, 1951, 264.

4. Kant, Immanuel. "Crítica del Juicio." Translation from German "Kritik der Urteilskraft" by Manuel García Morente. Buenos Aires: El Ateneo, 1951, 265.

5. Gramont, Jérôme de. Translated from "Kant et la question de l'affectivité. Lecture de la Troisième Critique." Paris: Librairie Philosophique J. Vrin, 1996, 97.

6. Kant, Immanuel. "Crítica del Juicio.” Translation from German "Kritik der Urteilskraft” by Manuel García Morente. Buenos Aires: El Ateneo, 1951, 266.

7. Kant, Immanuel. "Crítica del Juicio." Translation from German "Kritik der Urteilskraft" by Manuel García Morente. Buenos Aires: El Ateneo, 1951, 267. ... But like in a judgement in which something is simply referred to as big it is not only meant that the object has a magnitude, but this magnitude is attributed to the object, at the same time, with advantage over many other objects of the same kind, without declaring that advantage as determinant. It turns out that a base is assigned to the base of the judgement which is supposed to be accepted as exactly the same by everybody, but is not applicable to any logic judgement (mathematically determined), but only to the aesthetic judgement of magnitude, because it is a merely subjective measurement which is on the basis of the judgement which reflects on the magnitudes.

8. Kant, Immanuel. "Crítica del Juicio." Translation from German "Kritik der Urteilskraft" by Manuel García Morente. Buenos Aires: El Ateneo, 1951, 274.

9. Makkreel, Rudolf. "Imagination and Temporality in Kant's Theory of the Sublime," The Journal of Aesthetics and Art Criticism." 1984, 8.

10. Kant, Immanuel. "Crítica del Juicio." Translation from German "Kritik der Urteilskraft" by Manuel García Morente. Buenos Aires: El Ateneo, 1951, 275.

11. Kant, Immanuel. "Crítica del Juicio." Translation from German "Kritik der Urteilskraft" by Manuel García Morente. Buenos Aires: El Ateneo, 1951, 276.

12. Kant, Immanuel. "Crítica del Juicio.” Translation from German "Kritik der Urteilskraft” by Manuel García Morente. Buenos Aires: El Ateneo, 1951, 277.

13. Kant, Immanuel. "Crítica del Juicio." Translation from German "Kritik der Urteilskraft” by Manuel García Morente. Buenos Aires: El Ateneo, 1951, 280. The aptitude of the spirit for the feeling of the sublime demands a receptiveness of spirit to ideas, then precisely in the inadequacy of nature to ideas and, therefore, only under the supposition of them and a tension of imagination to deal with nature as a way of thinking of them, arouses the frightening for sensibility, which, at the same time, is attractive, because it is a violence that reason exerts on sensibility only to expand it adequately to its own sphere (the practical one) and let it see beyond the infinite, which is an abyss for the practical sphere.

14. Kant, Immanuel. "Crítica del Juicio." Translation from German "Kritik der Urteilskraft" by Manuel García Morente. Buenos Aires: El Ateneo, 1951, 281. But both things [the feeling of the beautiful and the feeling of the sublime] we ask of each individual and we take them for granted if man possesses some kind of culture: only with the difference that the first one, since judgement in it refers the image only to the understanding as faculty of the concepts, we ask, just like that, of each individual; but the second one, since the judgement in it refers imagination to reason as faculty of the ideas, we demand only under a subjective supposition (which, however, we think that we are authorized to ask of each individual), namely, that of the moral feeling in man, and that is why we attribute, for our part, necessity to that aesthetic judgement.

15. Gramont, Jérôme de. Ob. Cit. 106.

16. Jurado, Alicia. "Genio y figura de Jorge Luis Borges.” Buenos Aires: EUDEBA, 1964, 100.

17. Alazraky, Jaime. "Versiones. Inversiones. Reversiones. El espejo como modelo estructural del relato en los cuentos de Borges." Spain: Gredos, 1977, 106.

18. Borges, Jorge Luis. "La biblioteca de Babel. Obras completas 1.” Buenos Aires: Sudamericana, 2016, 762.

19. Borges, Jorge Luis. "La biblioteca de Babel." 762. 
20. Pineda, Antonio Cachero. "Literatura, comunicación y caos: una lectura de Jorge Luis Borges.” España: Universidad de Sevilla, 4.

21. Borges, Jorge Luis. "La biblioteca de Babel." 763-4.

22. Alazraky, Jaime. "Versiones. Inversiones. Reversiones. El espejo como modelo estructural del relato en los cuentos de Borges.” Spain: Gredos, 1977, 103.

23. Borges, Jorge Luis. "El jardín de los senderos que se bifurcan.” 775-6.

24. Alazraki, Jaime. "Versiones. Inversiones. Reversiones. El espejo como modelo estructural del relato en los cuentos de Borges." 74.

25. Borges, Jorge Luis. "E1 Aleph." 931.

26. Borges, Jorge Luis. "El Aleph." 927.

27. Borges, Jorge Luis. "El Aleph.” 929.

28. Borges, Jorge Luis. "El Aleph.” 929.

29. Kant, Immanuel. "Crítica de la razón pura." Translation by Mario Caimi. Mexico: Fondo del Cultura Económica, 2011, 106.

30. Alazraki, Jaime. "Versiones. Inversiones. Reversiones. El espejo como modelo estructural del relato en los cuentos de Borges." 109.

31. Borges, Jorge Luis. "El jardín de los senderos que se bifurcan.” 771.

32. Borges, Jorge Luis. "El Aleph.” 922.

33. Gramont, Jérôme de. Ob. Cit. 96.

34. Borges, Jorge Luis. "El Aleph.” 929.

35. Gramont, Jérôme de. Ob. Cit. 109. 